\title{
近接場偏光を用いた過渡温度応答検出による熱物性計測法の開発
}

\section{Development of Thermophysical Property Sensing Technique using Near-field Optical Polarization}

\author{
○学 百上徹 (慶大院)＼cjkstart正＼cjkstart田口良広 (慶大理工，さきがけ)
}

Toru Momogami ${ }^{1}$ and Yoshihiro Taguchi ${ }^{2,3}$

${ }^{1}$ School of Integrated Design Engineering, Keio University, Yokohama, 223-8522, Japan

${ }^{2}$ Department of System Design Engineering, Keio University, Yokohama, 223-8522, Japan

${ }^{3}$ JST, PRESTO, 4-1-8 Honcho, Kawaguchi, Saitama, Japan.

近年ナノイヤ半導体デバイスの小型化や高集積化に伴い, 試料内部のナノスケール領域において高電流密度の電 流が流れることが考えられる.これによりエレクトロマイグレーションやサーモマイグレーションと呼ばれるデバイスの破壊 や電流による多量の熱が発生し本来の性能を発揮できないことが問題となる. そこでエレクトロマイグレーションの発生原 理の解明や製造段階での熱設計の重要性が高まっている. 従来のエレクトロマイグレーション診断法としてロックイン赤 外発熱解析と呼ばれるショート等に伴う発熱箇所を赤外線カメラにより特定する方法が挙げられる. しかしこの方法にお ける空間分解能はカメラに依存し数 $\mu \mathrm{m}$ 程度に制限される. またエレクトロマイグレーションの発生段階しして試料に空 孔やクラックが生じ, これにより空孔やクラック付近において局所的に発熱が生じることが知られている. そこで本研究で は微小開口に生じる近接場光といら数百 $\mathrm{nm}$ の光源を用いて高空間分解能を実現し, 近接場光における偏光面回転の 温度依存性を用いた温度測定とポンプ・プローブ法による過渡応答解析手法を組み合わせ, 局所熱伝導率を測定可能 とする近接場偏光熱顕微鏡 (P-NOTN: Polarized Near-field Optical Thermal Nanoscopy) の開発を行っている.これによ

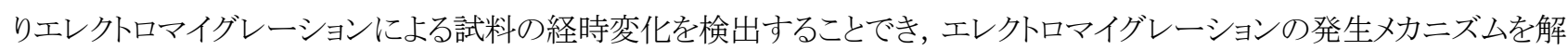
明することが可能となる. また熱物性の測定を行うことができることからデバイス作製における熱設計を行えることから本研 究が非常に有用性の高いものであるといえる. 本稿では測定試料を Pt ナノワイヤとして, 対物レンズによって集光したバ ルク光源を用いて, 時間領域サーモリフレクタンス法 (TDTR 法) により温度過渡応答の観測を行った. Fig. 1 に光学系 を示し, Fig. 2 に TDTR 法によって得られた結果を示す.さらに TDTR 法によって得られた結果から有限差分時間領域 法 (FDTD 法) を用いた数值シミュレーションより, 近接場光による光学的加熱の妥当性と試料の偏光面回転量の検証 を行ったので報告する.

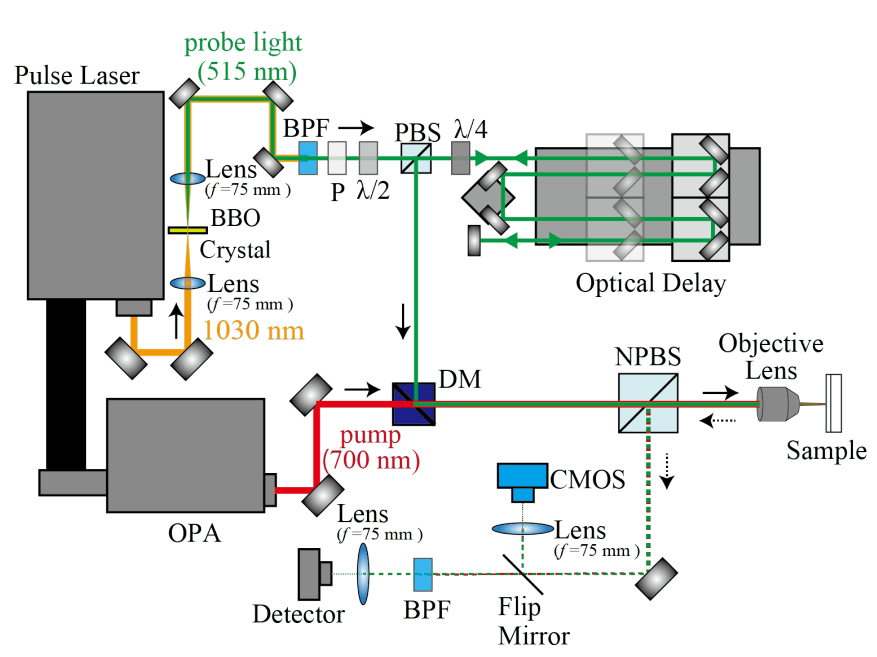

Fig. 1 Optical system for TDTR methods

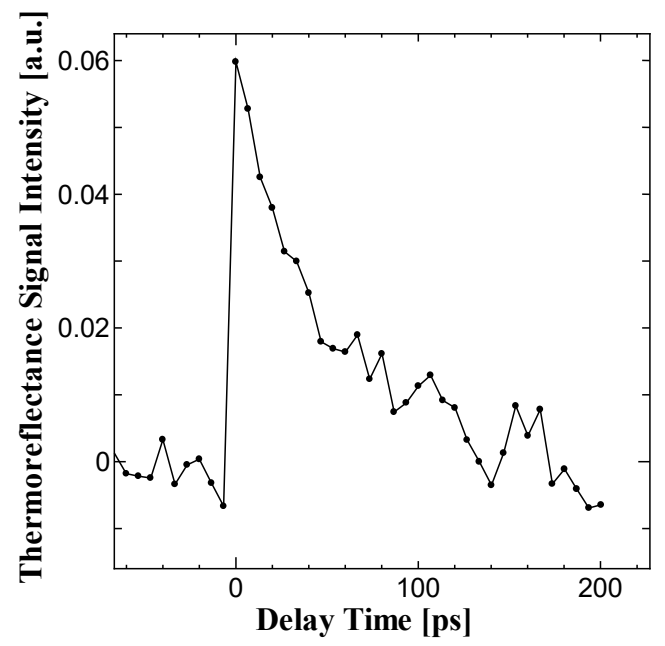

Fig.2 The acquired thermoreflectance signal 